\title{
1 The impact of NOx emissions from lightning on the production 2 of aviation-induced ozone
}

3 Arezoo Khodayari ${ }^{1,2}$, Francis Vitt ${ }^{3}$, Daniel Phoenix ${ }^{1}$ and Donald J. Wuebbles ${ }^{1}$

${ }^{1}$ Department of Atmospheric Sciences, University of Illinois at Urbana-Champaign, USA.

${ }^{2}$ Currently at the Department of Civil and Environmental Engineering, California State

6 University, Los Angeles, USA.

${ }^{3}$ National Center for Atmospheric Research, Boulder, CO, USA.

*Corresponding author address: Arezoo Khodayari, Department of Atmospheric Sciences, University of Illinois at Urbana-Champaign, 105 S. Gregory St., Urbana, IL, 61801. E-mail address: akhoday2@illinois.edu

\begin{abstract}
Due to the non-linear nature of ozone production in the troposphere, ozone production as a function of aviation nitrogen oxide $\left(\mathrm{NOx}=\mathrm{NO}+\mathrm{NO}_{2}\right)$ emissions varies based on the background NOx levels. Of the several different sources of background NOx in the atmosphere, NOx from lightning (LNOx) contributes a substantial amount of NOx to the upper troposphere and has an effect on the ozone production efficiency, even though the LNOx source still has significant uncertainty. In this study, CAM5, the atmospheric component of the Community Earth System Model (CESM), was used to study the effect of uncertainties in NOx emissions from lightning on the production of aviation-induced ozone. Three sensitivity studies were analyzed with varying LNOx values of 3.7, 5, and $7.4 \mathrm{TgN} / \mathrm{yr}$, representing the best current range estimates for LNOx. Results show a decrease in the aviation-induced ozone production rate and radiative forcing $(\mathrm{RF})$ as LNOx increases. This is tied to the decreased ozone production under NOx saturated conditions. The ozone production per unit of NOx emission from lightning ranges from $2.38 \mathrm{TgO}_{3} / \mathrm{TgN}$ for the case with $3.7 \mathrm{TgN}$ from lightning to $0.97 \mathrm{TgO}_{3} / \mathrm{TgN}$ for the case with $7.4 \mathrm{TgN}$ from lightning. Similarly, the $\mathrm{O}_{3} \mathrm{RF}$ decreases from $43.9 \mathrm{~mW} / \mathrm{m} 2$ for the 3.7 $\mathrm{TgN} / \mathrm{yr}$ case to $34.3 \mathrm{~mW} / \mathrm{m} 2$ for $7.4 \mathrm{TgN} / \mathrm{yr}$ case. Understanding the current sensitivity of aviation-induced ozone production to the LNOx strength is important for reducing the uncertainty in ozone production from aviation NOx emissions.
\end{abstract}




\section{Introduction}

Nitrogen oxides $\left(\mathrm{NOx}=\mathrm{NO}+\mathrm{NO}_{2}\right)$ are important to tropospheric chemistry due to their role as a precursor of ozone [Crutzen, 1974]. NOx emissions in the upper troposphere are particularly important due to the pristine background atmosphere where additional NOx emissions can have a large impact on ozone production. A large anthropogenic source of NOx emissions in the upper troposphere is from commercial aircraft and these emissions are about four times more efficient in producing ozone $\left(\mathrm{O}_{3}\right)$ than ground sources [Hodnebrog et al., 2011].

Many past studies have examined the effects of aviation NOx emissions on ozone [e.g., Brasseur et al., 1998; IPCC, 1999; Grewe et al., 2002; Köhler et al., 2008; Hoor et al., 2009; Hodnebrog et al., 2011; Myhre et al., 2011; Köhler et al., 2013; Jacobson et al., 2013; Olsen et al., 2013b; Khodayari et al., 2014]. Of these studies, there exists a considerable range in the modeled difference in the increase in tropospheric ozone from aviation, from 2.3 to 3.0 $\mathrm{TgO}_{3} / \mathrm{TgN}$ [Olsen et al., 2013a] and 5.5 to $16.4 \mathrm{TgO}_{3} / \mathrm{TgN}$ [Lee et al., 2010]. These differences are likely due to several factors, among them, the upper tropospheric budget of background NOx and the non-linearity of ozone production relative to the background NOx concentration [IPCC, 1999]. Two dominant sources of NOx in the upper troposphere are production from lightning (LNOx) and emissions from aviation, with lightning being the largest non-aviation source of NOx [WMO, 1999]. However, the magnitude of NOx emissions from lightning has been one of the least known in the global NOx budget, with a current uncertainty range of 1-20 with the most probable range being 2-8 TgN/yr [Schumann and Huntreiser, 2007, and references therein]. Additionally, with the large error in the retrieval process of observational data of cloud to ground flashes and the uncertainty of energy dissipated from intracloud flashes, lightning parameterizations in CTMs may not accurately represent the vertical distribution of LNOx [Ott et al., 2010; Miyazaki et al., 2014]. While the contribution from aviation is reasonably well known [Wilkerson et al., 2010; Olsen et al., 2013a], the contribution from lightning is harder to accurately represent.

Another complication is that the production of ozone as a function of the background NOx level is non-linear [Isaksen et al., 1978; Lin et al., 1988; Groo $\beta$ et al., 1998; Jaeglé et al., 1999]. Ozone production is sensitive to the background concentrations of NOx and nonmethane 
hydrocarbons (NMHC or volatile organic compounds, VOC). Therefore, the efficiency and sign of ozone production depends on the background atmosphere and therefore, LNOx strength.

Numerous studies have shown that aviation NOx emissions increase ozone production in the upper troposphere [e.g. Brasseur et al., 1998; IPCC, 1999; Grewe et al., 2002; Köhler et al., 2008; Hoor et al., 2009; Hodnebrog et al., 2011; Myhre et al., 2011; Köhler et al., 2013; Jacobson et al., 2013; Olsen et al., 2013b; Khodayari et al., 2014]. Other studies have also shown that increases in the LNOx source increase ozone production in the background atmosphere [Lawrence et al., 1995; Brasseur et al., 1996; Lee et al., 1997; Berntsen and Isaksen, 1999; Kraabøl et al., 2002; Labrador et al., 2005; Schumann and Huntreiser, 2007; Wild, 2007; Allen et al., 2010; Liaskos et al., 2015]. A few studies have shown that increases in the LNOx source decrease the aviation-induced ozone production efficiency due to the high NOx/low VOC atmosphere [Brasseur et al., 1996; Berntsen and Isaksen, 1999]. Brasseur et al. [1996] found the production of aviation NOx-induced ozone was reduced by a factor of 2 when the lightning source was increased from $5 \mathrm{TgN} / \mathrm{yr}$ to $10 \mathrm{TgN} / \mathrm{yr}$ at $10 \mathrm{~km}$. Berntsen and Isaksen [1999] found a 1.5- 2.5 ppb maximum reduction of aviation-induced ozone when the NOx source from lightning was increased from $5 \mathrm{TgN} / \mathrm{yr}$ to $12 \mathrm{TgN} / \mathrm{yr}$.

Given the improvements in understanding of atmospheric chemistry and physics since these earlier studies, we found it worthwhile to investigate the effect of LNOx on the chemistry of the background atmosphere and on the production of aviation-induced ozone . Our study investigates the aviation-induced $\mathrm{O}_{3}$ production and radiative forcing from $\mathrm{O}_{3}$ for three different $\mathrm{LNOx}$ magnitudes using the most up-to-date aviation NOx emission inventory and a state-of-art climate-chemistry model. The updates in the emission inventory and the improvements in climate-chemistry modeling have led to higher model resolution, a more complete chemical mechanism and a more detailed representation of aerosols processes that are central to ozone chemistry and should lead to a more accurate estimate of the impact of LNOx on the production of aviation-induced ozone.

This study will investigate the effects of lightning NOx on ozone production with aviation NOx emissions using version 5 of the Community Atmosphere Model (CAM5) which is the atmospheric component of Community Earth System Model (CESM). Three sets of simulations were done with varying LNOx values of 3.7, 5.0, and 7.4 TgN/yr, in accordance with the current 
best estimate for LNOx, to analyze the effect of LNOx on the production of aviation-induced ozone. The rest of the paper is organized as follows. Section 2 gives a description of the model used and the simulations done, section 3 presents the results and discussion, and section 4 provides the concluding remarks.

\section{Model Description and Simulation Setup}

The Community Atmosphere Model version 5 (CAM5) was used for this study. CAM5 was configured with a horizontal resolution of $1.9^{\circ}$ latitude $\times 2.5^{\circ}$ longitude and 56 vertical levels from the surface to $\sim 3.5 \mathrm{hPa}$. The vertical resolution in the vicinity of the tropopause was about $1.3 \mathrm{~km}$. The photolysis scheme and gas phase mechanism, which includes 133 species and 330 photochemical reactions, is the same as in CAM4 and has been detailed in Lamarque et al. [2012]. The main improvement in CAM5 over its predecessor is its modal aerosol module (MAM) [Liu et al., 2012]. Two versions of MAM were developed, one with three lognormal modes (MAM3) and one with seven lognormal modes (MAM7). For this study we used MAM7, which represents Aitken, accumulation primary carbon, fine dust and sea salt, and coarse dust and sea salt modes. The mass and number mixing ratio for all aerosols in each mode is calculated, and the size distribution of aerosols, internal and external mixing, and physical, chemical and optical properties are simulated [Liu et al., 2012].

Simulations were run with specified dynamics ("off-line" mode) to reduce the year-to-year climate variability and better detect the aviation NOx signal. Being run in "off-line" mode, changes in the chemical constituents do not affect the dynamics. GEOS DAS v5.1 meteorology for the year 2005 [Rienecker et al. 2008] was used since it was the closest available assimilated meteorology data to the year of interest (2006). The AEDT aviation emissions analyses were used to obtain the aviation emissions for the year 2006 [Wilkerson et al., 2010; Olsen et al, 2013a; Brasseur et al., 2013]. The aviation NOx emissions had a horizontal resolution of $1^{\circ}$ latitude $\mathrm{x} 1^{\circ}$ longitude, vertical resolution of $150 \mathrm{~m}$, and hourly temporal resolution. The total $\mathrm{NO}_{\mathrm{X}}$ emissions amounted to $0.82 \mathrm{TgN} / \mathrm{yr}$. The IPCC RCP4.5 scenario [van Vuuren et al., 2011] for year 2005 was used to obtain the background emissions of non-aviation short-lived species (e.g., NOx, VOCs) while the Model of Emissions of Gases and Aerosols from Nature (MEGAN) [Guenther et al., 2006] was used to obtain the background emissions of biogenic species. Longer-lived species, e.g., carbon dioxide $\left(\mathrm{CO}_{2}\right)$, methane $\left(\mathrm{CH}_{4}\right)$, chlorofluorocarbons ( $\left.\mathrm{CFCs}\right)$, 
and nitrous oxide $\left(\mathrm{N}_{2} \mathrm{O}\right)$, were specified as boundary conditions based on the IPCC RCP4.5 scenario.

To investigate aviation-induced changes in $\mathrm{O}_{3}$, three sets of two simulations were performed; a simulation with aviation NOx emissions and a simulation without aviation NOx emissions (i.e. control simulation), each set with a different LNOx level. The simulations were run for 7 years to reach steady-state while cycling through the 2005 meteorology field to remove the year-to-year variability. Data from the $7^{\text {th }}$ year was used for analysis. Aviation-induced changes in $\mathrm{O}_{3}$ were calculated as the difference between the two runs. LNOx values of 3.7, 5 , and $7.4 \mathrm{TgN} / \mathrm{yr}$ were chosen in accordance with the range of current estimates, where the best estimate is $5 \mathrm{TgN} / \mathrm{yr}$ [Schumann and Huntrieser, 2007]. The set with $3.7 \mathrm{Tg} \mathrm{N} / \mathrm{yr}$ will be referred to as the reference case and the set with $5 \mathrm{TgN} / \mathrm{yr}$ and $7.4 \mathrm{TgN} / \mathrm{yr}$ will be referred to as case 2 and case 3, respectively. Since the only difference between the three sets of simulations were the LNOx levels, the differences in the aviation-induced $\mathrm{O}_{3}$ changes between the three sets were solely due to the differences in the level of LNOx.

\section{Results and Discussion}

\subsection{Chemistry diagnosis of the background atmosphere}

It has been previously shown that CAM reasonably reproduces the effects of aviation NOxinduced emissions on the distribution of tropospheric $\mathrm{O}_{3}$ and $\mathrm{NOx}$ [Weber, 2011 and Olsen et al., $2013 \mathrm{~b}$ ]. However, because of the central role of ozone in the troposphere and stratosphere and it is relation to NOx budget, simulated ozone under different level of NOx emissions from lightning (LNOx) and at representative altitudes is evaluated using an ozonesonde climatology [Tilmes et al., 2012]. This climatology comprises observations for the years 1995-2011 and includes averaged ozone profiles for 41 different ozonesonde stations that are grouped into 12 regions. For the purpose of our study, we evaluate ozone at four pressure levels covering the troposphere and lower stratosphere $(50,250,500$, and $900 \mathrm{hPa})$ over the 12 areas that are grouped into three larger regions (Tropics, Mid-Latitudes, and High Latitudes), as shown in Figure 1. Model results are interpolated horizontally to all the stations within each region, and 
averaged over each region. Figure 1 shows the comparison between model and observation in Taylor-like diagrams for each of the corresponding pressure levels and regions.

\section{Comparison to Ozonesondes}
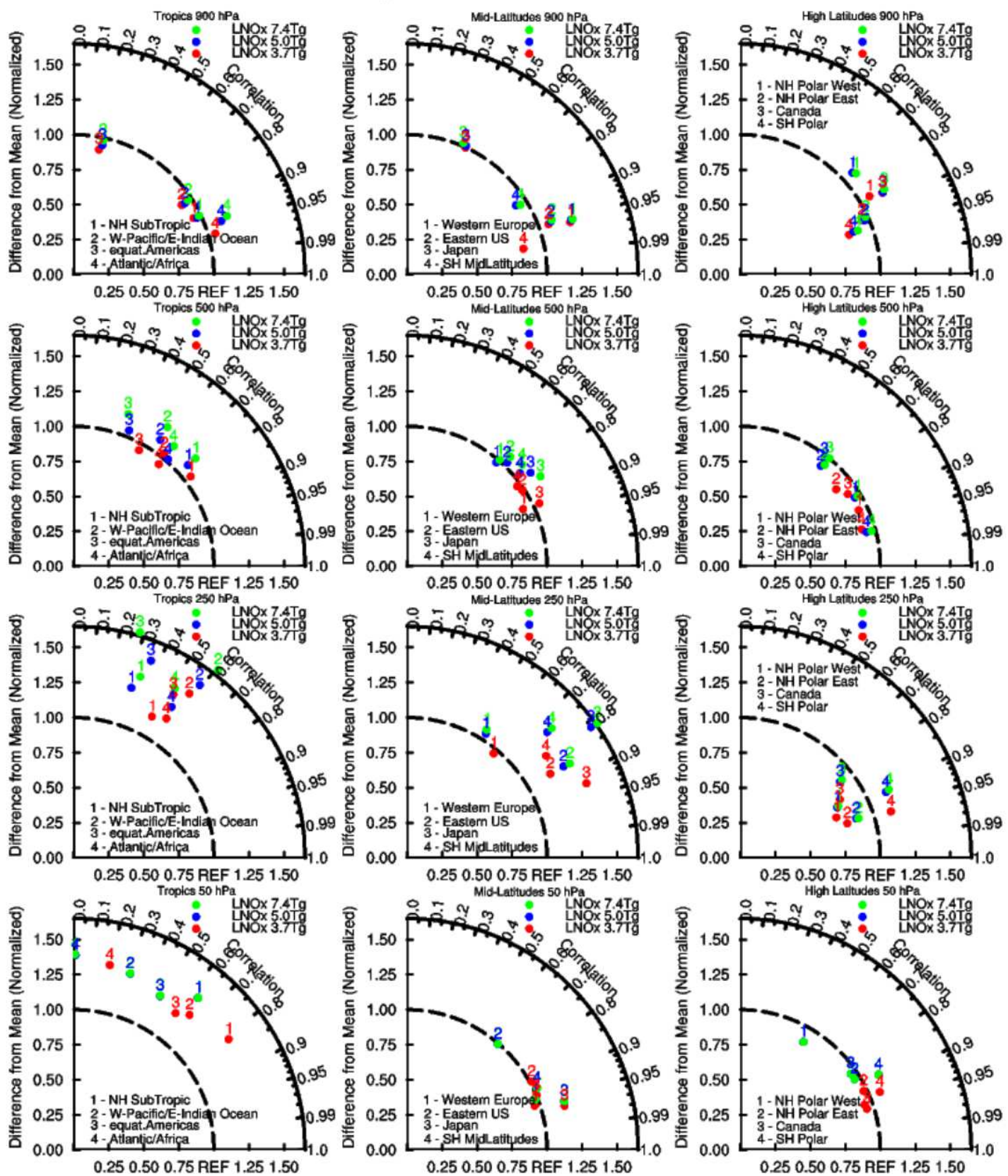

Figure 1. Taylor diagram of modeled annual average background ozone from the control runs against ozonesonde climatology for four pressure levels and three latitudinal regions. REF along the abscissa denotes the observations while the radial distance describes the normalized bias. The 
correlation between modeled and observed seasonality is shown by the azimuthal angle. It is noted that most aircrafts fly around $250 \mathrm{hPa}$.

As shown in Figure 1, the simulated ozone is within $10 \%$ of the observation in the boundary layer $(900 \mathrm{hPa})$ and at $500 \mathrm{hpa}$ which is the range of uncertainty for observation and is a good agreement. Moreover, with an exception of few locations in tropics the seasonal cycle is well reproduced at the boundary layer $(900 \mathrm{hPa})$ and $500 \mathrm{hpa}$. The bias in the tropics is likely due to a model estimated tropopause that is lower than observed and likely too much transport of ozone into the troposphere [Lamarque et al., 2012]. It is noted that the simulated ozone is very similar under different level of LNOx in the boundary layer $(900 \mathrm{hPa})$ and $500 \mathrm{hPa}$. On the other hand, the simulated ozone is less in agreement with observation at higher altitudes (e. g. at 250 and 50 hpa), especially in mid-latitudes and Tropics. Basically, at these attitudes the simulated ozone is mainly overestimated by about $25 \%$ in mid-latitudes and $50 \%$ in Tropics. The seasonal cycle with the exception of in Tropics is relatively well produced. Overall, as illustrated in Figure 1, ozone is well simulated in the troposphere, in the upper troposphere-lower stratosphere (UTLS) and stratosphere and it is overestimated in the tropical transition layer. It is also noted despite what was the case at the boundary layer and in the troposphere, at UTLS the simulated ozone varies at different level of NOx emissions from lightning and is lower at lower level of LNOx. As shown in Figure 1 at UTLS the simulated ozone is in a better agreement with observation at lower level of LNOx (i. e. $3.7 \mathrm{Tg} \mathrm{N}$ ). To further investigate the effect of different level of NOx emissions from lightning on the chemistry of the background atmosphere, the simulated level of $\mathrm{O}_{3}, \mathrm{NO}_{\mathrm{x}}, \mathrm{PAN}, \mathrm{HNO}_{3}, \mathrm{CO}$ as well as $\mathrm{OH}$, are compared to aircraft observations between 2-7 km, where the majority of the observations were taken [Emmons et al., 2000] as illustrated in Figure 2 .

In comparison to aircraft data, the simulated ozone is higher under higher level of NOx emissions from lightning, especially in the tropics and mid-latitudes, in agreement with ozonesonde observations. The simulated NOx is also in a good agreement with available aircraft observations, but it is underestimated in summer and fall in NH high-latitudes. The simulated NOx is also similar under different level of NOx emissions from lightning which indicates a higher shift of additional NOx to other NOy species under a higher level of NOx emission from 
lightning as shown in Figure 2. This observation is in agreement with higher level of simulated $\mathrm{HNO}_{3}$ and PAN, and $\mathrm{OH}$ under higher level of LNOx. The simulated $\mathrm{CO}$ in line with higher production of ozone is slightly lower under higher level of NOx emissions from lightning and is underestimated in all simulations. Overall, the differences between simulated results under different level of NOx emissions from lightning are within the variability of the observations.
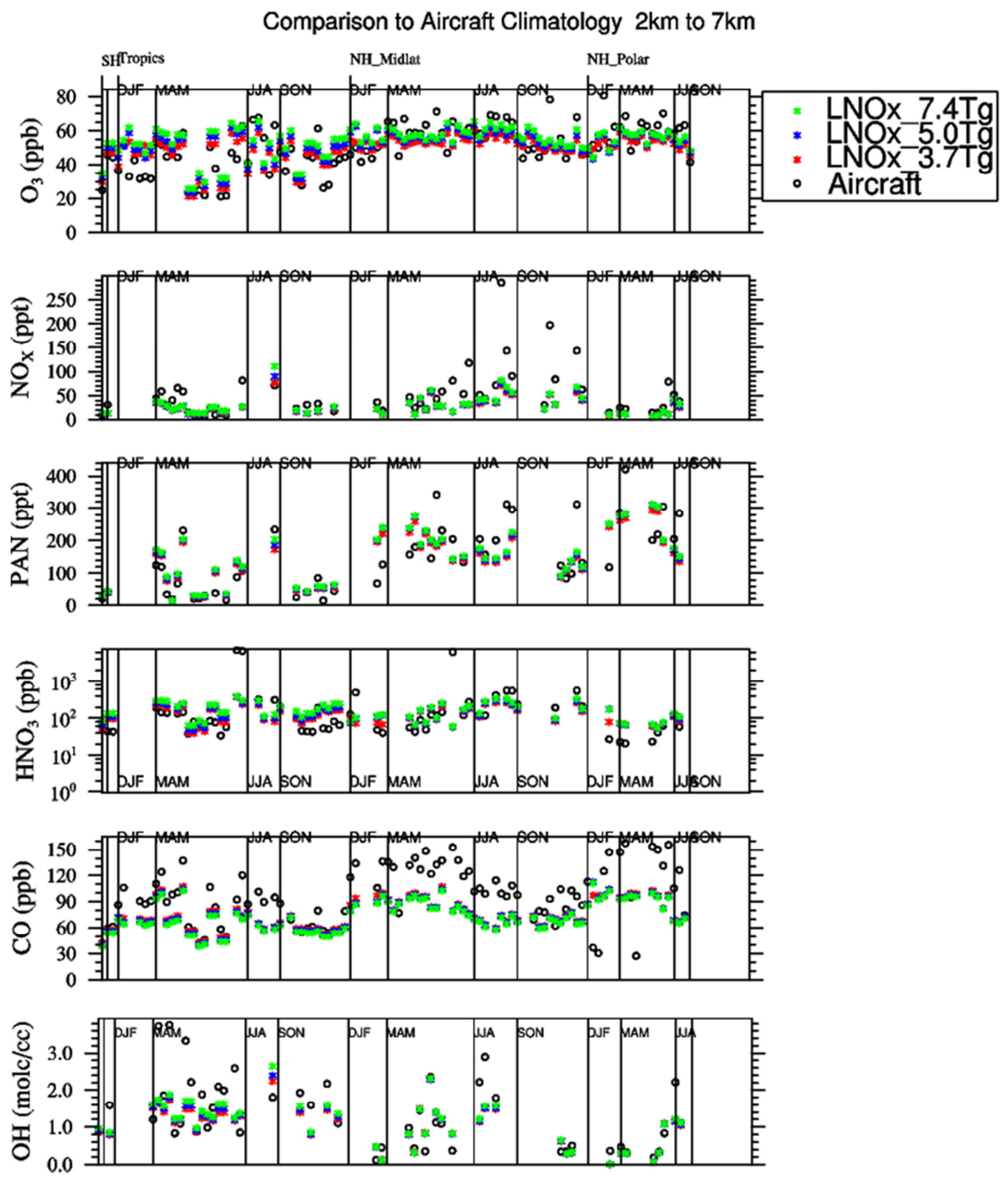
Figure 2. Comparison between aircraft observations over different regions and seasons and different model simulations derived by different level of LNOx emissions, averaged between 2 and $7 \mathrm{~km}$, for ozone, $\mathrm{NOx}, \mathrm{PAN}, \mathrm{HNO}_{3}, \mathrm{CO}$, and $\mathrm{OH}$ based on an updated version of the aircraft climatology by [Emmons et al., 2000], as described in detail in [Tilmes et al., 2015]. As discussed in Emmons et al. (2000), for each aircraft campaign, regions with high frequency occurrence of vertical profiles from the aircraft were recognized. Mean profiles of the examined species across all the campaigns were compiled over these regions with a $1 \mathrm{~km}$ vertical resolution. Profiles that were outliers were removed. The multiple data points within each region and season represent different location at which observations were made and model data were interpolated to the locations of the observational data for comparison purposes.

\subsection{Aviation-induced changes in ozone}

Due to complex photochemistry of ozone production, additional units of NOx emissions could result in both production and destruction of ozone [Lin et al., 1988]. As such, the production of ozone does not follow linearly with increasing concentrations of NOx since the destruction rates of NOx and odd hydrogen depend on the initial concentration of local NMHC and NOx in the background atmosphere [Lin et al., 1988]. Since NOx is a catalyst in ozone production process, its increase could increase the background $\mathrm{O}_{3}$ levels if the initial concentration of local NMHC and NOx in the background atmosphere favors ozone production (i.e. low NOx/NMHC ratio). According to our results and as shown in Figures 1and 2 the additional LNOx emissions led to more ozone production in the background atmosphere, such that there is a maximum zonal $\mathrm{O}_{3}$ increase of $63 \%$ between case $3(7.4 \mathrm{TgN} / \mathrm{yr})$ and the reference case (3.7 Tg N/yr) between 100$200 \mathrm{hPa}$ over $30-60^{\circ} \mathrm{N}$. However, due to high NOx/NMHC ratio under high LNOx emissions, aviation-induced production of ozone at cruise altitudes deceased with increasing LNOx emissions. Figure 3 shows the changes in aviation-induced ozone production in the free troposphere for the 3 cases. The production rate of ozone has been defined as the instantaneous production minus loss for ozone (molecules $\mathrm{cm}^{-3} \mathrm{~S}^{-1}$ ) for a model grid box integrated over the global and expressed in $\mathrm{Pa}^{-1}$ to account for the thickness of the box. As shown in Fig. 3, the net aviation-induced ozone production at cruise altitude is largest in the reference case and smallest for case 3. Therefore, aviation-induced ozone production rate is greatest for the case with the lowest LNOx level. 


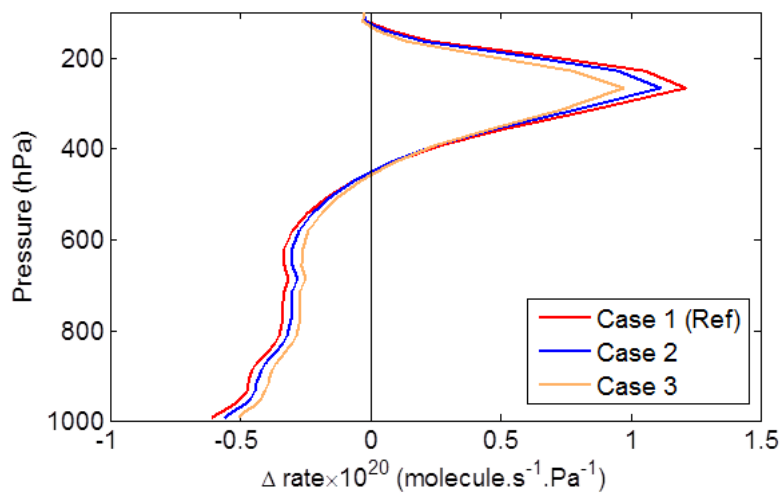

Figure 3. Aviation-induced ozone net production rate in the free troposphere for the 3 cases. The net production rate of ozone for the reference case (case with $3.7 \mathrm{Tg} \mathrm{N} / \mathrm{yr} \mathrm{NOx}$ emissions from lightning) is indicated by the red line. The blue and orange lines show the net production rate of ozone for case 2 and case 3 , respectively.

The global aviation-induced $\mathrm{O}_{3}$ burden and $\mathrm{O}_{3}-\mathrm{RF}$ are shown in Figure 4 and Table 1. As expected by the higher aviation-induced ozone production rate under the reference case (low LNOx) the aviation-induced global tropospheric $\mathrm{O}_{3}$ burden and $\mathrm{O}_{3}-\mathrm{RF}$ are largest for the reference case with a global $\mathrm{O}_{3}$ burden of $8.8 \mathrm{Tg}$ and $\mathrm{O}_{3}-\mathrm{RF}$ of $43.9 \mathrm{mWm}^{-2}$. For a doubling of the LNOx source from 3.7 to $7.4 \mathrm{TgN} / \mathrm{yr}$, the aviation induced global tropospheric $\mathrm{O}_{3}$ burden and $\mathrm{O}_{3}-\mathrm{RF}$ decrease by $18 \%$ and $22 \%$, respectively. Furthermore, the global tropospheric aviationinduced ozone burden per Tg of NOx emitted from lightning decreases from $2.38 \mathrm{TgO}_{3} / \mathrm{TgNOx}$ for the reference case to $0.97 \mathrm{TgO}_{3} / \mathrm{TgLNOx}$ for case 3 , as shown in Table 1 .
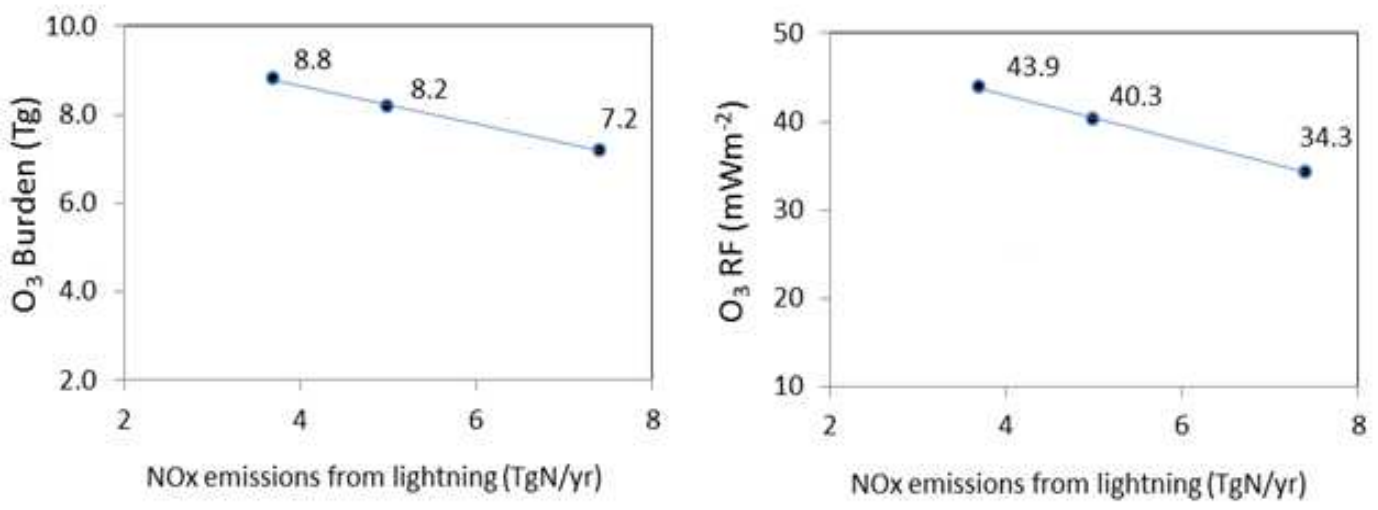

Figure 4. Aviation-induced $\mathrm{O}_{3} \mathrm{RF}\left(\mathrm{mW} / \mathrm{m}^{2}\right)$ and $\mathrm{O}_{3}$ Burden $(\mathrm{Tg})$ from 3 different LNOx sources (3.7 Tg, 5.0 Tg, and 7.4 Tg). 
Table 1. LNOx source and corresponding aviation-induced $\mathrm{O}_{3}$ burden, $\mathrm{O}_{3}$ Radiative Forcing, and $\mathrm{O}_{3}$ burden per Tg of LNOx

\begin{tabular}{|l|c|c|c|}
\hline LNOx Source $(\mathrm{TgN})$ & $\mathrm{O}_{3}$ burden $(\mathrm{Tg})$ & $\mathrm{O}_{3} \mathrm{RF}\left(\mathrm{mW} / \mathrm{m}^{2}\right)$ & $\mathrm{O}_{3} / \mathrm{LNOx}\left(\mathrm{Tg} \mathrm{O}_{3} / \mathrm{TgN}\right)$ \\
\hline 3.7 & 8.8 & 43.9 & 2.38 \\
\hline 5.0 & 8.2 & 40.3 & 1.64 \\
\hline 7.4 & 7.2 & 34.3 & 0.97 \\
\hline
\end{tabular}

In previous studies, Brasseur et al. [1996] and Berntsen and Isaksen [1999] also looked at the effect of varying LNOx levels on aviation-induced ozone at cruise altitudes. Brasseur et al. [1996] found that for a doubling of the LNOx source from $5 \mathrm{TgN} / \mathrm{yr}$ to $10 \mathrm{TgN} / \mathrm{yr}$, the zonally averaged aviation-induced tropospheric ozone production was reduced by a factor of 2 , from $4.5 \%$ to $2.4 \%$ of the background ozone in the northern hemisphere. Our results show an $14 \%$ decrease in the northern hemisphere (or a reduction by a factor of 1.2 , from $3.4 \%$ to $2.8 \%$ ) in the zonally averaged aviation-induced tropospheric ozone production for a doubling of the LNOx source from 3.7 to $7.4 \mathrm{TgN} / \mathrm{yr}$. Berntsen and Isaksen [1999] found, for an increase of the LNOx strength from $5 \mathrm{TgN} / \mathrm{yr}$ to $12 \mathrm{TgN} / \mathrm{yr}$, a maximum reduction of aviation-induced ozone production of 1.5-2.5 ppb in northern mid- and high-latitudes during the summer. In our study, we estimate a maximum increase of $1 \mathrm{ppb}$ in aviation-induced ozone production from a decrease in the LNOx strength from $3.7 \mathrm{TgN} / \mathrm{yr}$ to $7.4 \mathrm{TgN} / \mathrm{yr}$ over northern mid- and high-latitudes during summer.

The difference between these two studies and ours is likely due to the non-linear relationship between the amount of NOx emissions from lightning and the amount of aviation-induced ozone as well as the following reasons. The 3-dimensional chemical tracer model (CTM) used by Brasseur et al. [1996] had a 5 x 5 degree horizontal resolution with 25 vertical levels and included 50 species, 6 NMHCs and several oxygenated organic species including PAN and other organic nitrates. In the study by Berntsen and Isaksen [1999], the 3-dimensional CTM used had an $8 \times 10$ degree horizontal resolution with 9 vertical layers. The model had photochemical scheme of 55 chemical components and 120 gas-phase reactions. The chemical scheme was extended to include the degradation of propane, which gives acetone. However, there were no 
direct emissions of acetone (an important source of $\mathrm{HOx}$ ) in the model. This may have important implications on their result as Müller and Brasseur [1999] found a 20\% reduction in $\mathrm{O}_{3}$ mixing ratios when emissions of acetone were not included. Our study uses CAM5 with chemistry, on a $1.9 \times 2.5$ degree horizontal resolution with 30 vertical levels. CAM5 has tropospheric and stratospheric chemistry with 133 species, 330 photochemical reactions, and a modal aerosol module. We also use aviation NOx emissions from the year 2006 (i. e. $0.82 \mathrm{TgN}$ ) while Brasseur et al. [1996] and Berntsen and Isaksen [1999] used aircraft emissions from 1990 (i. e. $0.44 \mathrm{TgN}$ ) and 1996 (i. e. $0.52 \mathrm{TgN}$ ), respectively. The updates in our model resolution and chemistry scheme, with more recent aviation emissions, provide a current evaluation of the impact of NOx emissions from lighting on the production of aviation-induced $\mathrm{O}_{3}$.

As improvements in chemistry-climate models are important for evaluating aviation-induced ozone production, reducing the LNOx uncertainty is also important. As was seen in Figure 1 and 2 the level of NOx emission from lightning affects the simulation of the background atmosphere and its agreement with observations. In this study the simulated ozone in the background atmosphere was in a better agreement with observation under a low LNOx emission case $(3.7 \mathrm{Tg}$ $\mathrm{N} / \mathrm{yr}$ ). Schumann and Huntrieser [2007] estimated a range of 2-8 $\mathrm{TgNyr}^{-1}$ with a best estimate of $5 \mathrm{TgNyr}^{-1}$ in a review of 30 years of lightning studies. The techniques these studies used to estimate LNOx fell into three categories: flash extrapolation, storm extrapolation, and global model fit. Of these methods, the global model fit had the lowest range of uncertainty. However, at the time of publication, only a subset of observations had been compared to the model simulations. Furthermore, the model estimates were based on meteorological parameters and did not account for all the parameters that are important for lightning and LNOx production [Schumann and Huntrieser, 2007].

More recent studies have found similar best estimates with reduced uncertainty. Murray et al. [2012] estimated a global annual LNOx source of 5.5-6.5 $\mathrm{TgNyr}^{-1}$ after applying a scaling factor to improve the representation of lightning in CTMs, using Lightning Imaging Sensor (LIS) /Optical Transient Detector (OTD) satellite observations. Stravrakou et al. [2013] estimated a range of 3.3-5.9 $\mathrm{TgNyr}^{-1}$ after considering recent developments in the understanding of NOx sink pathways with top-down emissions derived from inverse modelling. Miyazaki et al. [2014] estimated a global annual LNOx source of 4.9-7.7 $\mathrm{TgNyr}^{-1}$ from assimilating satellite 
observations of $\mathrm{NO}_{2}, \mathrm{O}_{3}, \mathrm{HNO}_{3}$, and $\mathrm{CO}$ in a chemical transport model. While more recent studies have better constrained the LNOx source, improvements still need to be made in the simulated lightning variability, the accuracy of simulated atmospheric electricity, convective parameterizations, and vertical emissions profiles [Schumann and Huntrieser, 2007].

\section{Conclusions}

We used the most up-to-date aviation emission inventory and a state-of-the art climatechemistry model, CAM5, to evaluate the impact of LNOx on the production of aviation-induced ozone. CAM5 has a higher model resolution, more complete chemical mechanism and a more detailed representation of aerosol processes compared to previous models that were used for evaluating the impact of LNOx on the production of aviation-induced ozone. As such the result presented in this study can be considered the most current evaluation of the impact of LNOx on the production of aviation-induced ozone.

CAM5 simulations with varying LNOx source strengths show that increasing the LNOx source from 3.7 to $7.4 \mathrm{TgN} / \mathrm{yr}$ decreases the global mean aviation-induced $\mathrm{O}_{3}$ burden and $\mathrm{O}_{3}-\mathrm{RF}$ by about $18 \%$ and $22 \%$, respectively with a maximum reduction in the aviation-induced surface ozone perturbation of $1 \mathrm{ppb}$. Additionally, for a doubling of the LNOx strength, the NH zonal mean $\mathrm{O}_{3}$ perturbation is reduced by a factor of 1.2 . The greatest change in the net ozone production rate in the three cases is in the Northern Hemisphere at subsonic aircraft cruise altitudes. Previous studies show similar relationships between LNOx levels and aviation-induced ozone production, but the magnitude of these changes is lower in our study.

Our study provides a current estimate of the effects of LNOx on aviation-induced ozone. The range in uncertainty for both aviation-induced tropospheric ozone and the NOx source from lightning is large (2.3 to $3.0 \mathrm{TgO}_{3} / \mathrm{TgN}$ [Olsen et al., 2013a] and 5.5 to $16.4 \mathrm{TgO}_{3} / \mathrm{TgN}$ [Lee et al., 2010] for aviation-induced tropospheric ozone and 2 to $8 \mathrm{TgN}$ [Schumann and Huntrieser, 2007] for LNOx). The uncertainty in aviation-induced tropospheric ozone is likely due to differences in the details representations of the physics and chemistry of the background 
atmosphere in different models among which representation of NOx emissions from lightning is an important one [Olsen et al., 2013a]. As such assessing the current model sensitivity of aviation-induced ozone to LNOx is important to reduce the uncertainty in aviation-induced ozone production. More importantly, a better understanding of the magnitude of the NOx sources and sinks from lightning is needed to better quantify the impact of aviation emissions on ozone production. The results from this study suggest that there remain uncertainties in the effects of NOx emissions from lightning on aviation-induced ozone. It further points to the necessity of more detailed critical testing of models sensitivity to the effect of NOx emissions from lightning and a better understanding of the magnitude of the NOx emission from lightning as perhaps the most important path to reducing these uncertainties.

\section{Acknowledgements}

The authors would like to thank the Federal Aviation Administration, Aviation Climate Change Research Initiative (ACCRI) for support under Contract \#: 10-C-NE-UI amendment 001 and The Partnership for AiR Transportation Noise and Emissions Reduction (PARTNER). The opinions, findings, and conclusions or recommendations expressed in this material are those of the authors and do not necessarily reflect the views of ACCRI, PARTNER, or the FAA. We would like to acknowledge high-performance computing support from Yellowstone (ark:/85065/d7wd3xhc) provided by NCAR's Computational and Information Systems Laboratory, sponsored by the National Science Foundation.

The AEDT aviation emissions dataset used in this study is assessable via coordination with the Department of Transportation's (DOT) Volpe Center.

\section{References}

Allen, D., K. Pickering, B. Duncan, and M. Damon (2010), Impact of lightning NO emissions on North American photochemistry as determined using the Global Modeling Initiative (GMI) model, J. Geophys. Res., 115, D22301. 
Banerjee et al. (2014), Lightning NOx, a key chemistry-climate interaction: impacts of future climate change and consequences for tropospheric oxidising capacity, Atmos. Chem. Phys., 14, 9871-9881.

Berntsen, T. K. and I.S.A. Isaksen (1999), Effects of lightning and convection on changes in tropospheric ozone due to NOx emissions from aircraft, Tellus, 51B, 766-788.

Brasseur, G. P., J.-F. Müller, and C. Granier (1996), Atmospheric impact of NOx emissions by subsonic aircraft: A three-dimensional study, J. Geophys. Res., 101, D1, 1423-1428.

Brasseur, G. P., D. A. Hauglustaine, S. Walters, P. J. Rasch, J.-F. Müller, and X. X. Tie (1998), MOZART, a global chemical transport model for ozone and related chemical tracers (1), $J$. Geophys. Res., 103, D21, 28265-28289.

Brasseur, G. P., A. Gettelman, M. Jacobson, P. Minnis, J. Penner, R. Prinn, H. B. Selkirk, N. Unger, H.-W. Wong, D. J. Wuebbles, P. Yang, R. Halthore and S. D. Jacob (2013), Aviation Climate Change Research Initiative (ACCRI) Phase II Report, Federal Aviation Administration, Washington, D. C.

Crutzen, P.J. (1974), Photochemical reactions initiated by and influencing ozone in unpolluted tropospheric air, Tellus, 26, 47-57.

Emmons, L. K., D. A. Hauglustaine, J.-F. Müller, M. A. Carroll, G. P. Brasseur, D. Brunner, J. Staehelin, V. Thouret, and A. Marenco (2000), Data composites of airborne observations of tropospheric ozone and its precursors, J. Geophys. Res., 105, 20497- 20538, doi:10.1029/2000JD900232.

Emmons, L. K., S. Walters, P. G. Hess, J.-F. Lamarque, G. G. Pfister, D. Fillmore, C. Granier, A. Guenther, D. Kinnison, T. Laepple, J. Orlando, X. Tie, G. Tyndall, C. Wiedinmyer, S. L. Baughcum, and S. Kloster, (2010), Description and evaluation of the Model for Ozone and Related chemical Tracers, version 4 (MOZART-4), Geosci. Model Dev., 3, 43-67, doi:10.5194/gmd3-43-2010, 2010.

Grewe, V., M. Dameris, C. Fitchter, and R. Sausen (2002), Impact of aircraft NOx emissions. Part 1: Interactively coupled climate-chemistry simulations and sensitivities to climate-chemistry feedback, lightning and model resolution, Meteorologische Zeitschrift, 11(3), 177-186.

Grooß, J.-U., C. Brühl, and T. Peter (1998), Impact of aircraft emissions on tropospheric and stratospheric ozone. Part 1: Chemistry and 2-D model results, Atmos. Environ., 32(18), 31733184.

Guenther A., T. Karl, P. Harley, C. Wiedinmyer, P. I. Palmer, and C. Geron (2006), Estimates of global terrestrial isoprene emissions using MEGAN (Model of Emissions of Gases and Aerosols from Nature), Atmos. Chem. Phys., 6, 3181-3210. 
Hoor, P., et al. (2009), The Impact of Traffic Emissions on Atmospheric Ozone and OH: results from QUANTIFY, Atmos. Chem. Phys., 9, 3113-36.

Hodnebrog, Ø., T. K. Berntsen, O. Dessens, M. Gauss, V. Grewe, I. S. A. Isaksen, B. Koffi, G. Myhre, D. Olivié, M. J. Prather, J. A. Pyle, F. Stordal, S. Szopa, Q. Tang, P. Velthoven, J. E. Williams, and K. Ødemark (2011), Future impact of non-land based traffic emissions on atmospheric ozone and $\mathrm{OH}-$ an optimistic scenario and a possible mitigation strategy, Atmos. Chem. Phys., 11, 11293-11317.

IPCC (1999), Aviation and the global atmosphere, Intergovernmental Panel on Climate Change, edited by: Penner, J. E., Lister, D.H., Griggs, D.J., Dokken, D.J., McFarland, M., Cambridge University Press, Cambridge, UK.

Isaksen, I. S. A., Ø. Hov, and E. Hesstvedt (1978), Ozone generation over rural areas, Environ. Sci. Technol., 12, 1279-1284.

Jacobson, M. Z., J. T. Wilkerson, A. D. Naiman, and S. K. Lele (2013), The effects of aircraft on climate and pollution. Part II: 20-year impacts of exhuaust from all commercial aircraft worldwide treated individually at the subgrid scale, Faraday Discuss., 165, 369-382.

Jaeglé, L., D. J. Jacob, W. H. Brune, I. C. Faloona, D. Tan., Y. Kondo, G. W. Sachse, B. Anderson, G. L. Gregory, S. Vay, H. B. Singh, D. R. Blake, R. Shetter (1999), Ozone production in the upper troposphere and the influence of aircraft during SONEX: Approach of NOxsaturated conditions, Geophys. Res. Lett., 26(20), 3081-3084.

Khodayari, A., et al. (2014), Aviation 2006 NOx-induced effects on atmospheric ozone and OH in Community Earth System Model (CESM), Atmos. Chem. Phys., 14, 9925-9939.

Köhler, M. O., G. Radel, O. Dessens, K. P. Shine, H. L. Rogers, O. Wild, and J. A. Pyle (2008), Impact of perturbations to nitrogen oxide emissions from global aviation, J. Geophys. Res., 113, D11305.

Köhler, M. O., G. Rädel, K. P. Shine, H. L. Rogers, and J. A. Pyle (2013), Latitudinal variation of the effect of aviation NOx emissions on atmospheric ozone and methane and related climate metrics, Atmos. Environ., 64, 1-9.

Kraabøl, A. G., T. K. Berntsen, J. K. Sundet, and F. Stordal (2002), Impacts of NOx emissions from subsonic aircraft in a global three-dimensional chemistry transport model including plume processes, J. Geophys. Res., 107(D22), 4655.

Labrador, L. J., R. Kuhlmann, and M. G. Lawrence (2005), The effects of lightning-produced NOx and its vertical distribution on atmospheric chemistry: sensitivity simulations with MATCH-MPIC, Atmos. Chem. Phys., 5, 1815-1834.

Lamarque, J.-F., L. K. Emmons, P. G. Hess, D. E. Kinnison, S. Tilmes, F. Vitt, C. L. Heald, E. A. Holland, P. H. Lauritzen, J. Neu, J. J. Orlando, P. J. Rasch and G. K. Tyndall (2012), CAM-chem: description and 
evaluation of interactive atmospheric chemistry in the Community Earth System Model, Geosci. Model Dev., 5, 369-411, doi:10.5194/gmd-5-369-2012.

Lawrence, M. G., W. L. Chameides, P. S. Kasibhatla, H. Levy II, and W. Moxim (1995), Lightning and atmospheric chemistry: The rate of atmospheric NO production, Vol. I, pp. 189202, CRC Press, Inc.

Lee, D. S., I. Köhler, E. Grobler, F. Rohrer, R. Sausen, L. Gallardo-Klenner, J. G. J. Olivier, F. J. Dentener, and A. F. Bouwman (1997), Estimations of global NOx emissions and their uncertainties, Atmos. Environ., 31, 1735-1749.

Lee, D. S., et al. (2010), Transport impacts on atmosphere and climate: Aviation, Atmos. Environ., 44, 4678-4734.

Liaskos, C. E., D. J. Allen, and K. E. Pickering (2015), Sensitivity of tropical tropospheric composition to lightning NOx production as determined by the NASA GEOS-Replay model, $J$. Geophys. Res. Atmos., 120, doi:10.1002/2014JD022987.

Lin, X., M. Trainer, and S. C. Liu (1988), On the Nonlinearity of the tropospheric ozone production, J. Geophys. Res., 93(D12), 15879-15888.

Liu, X., et al. (2012), Toward a minimal representation of aerosols in climate models: description and evaluation in the Community Atmosphere Model CAM5, Geosci. Model Dev., 54, 709-739.

Miyazaki, K., H. J. Eskes, K. Sudo, and C. Zhang (2014), Global lightning NOx production estimated by an assimilation of multiple satellite data sets, Atmos. Chem. Phys., 14, 3277-3305.

Müller, J. F., and G. Brasseur (1999), Sources of upper tropospheric HOx: A three dimensional study, J. Geophys. Res., 104(D1), 1705-1715.

Myhre, G., et al. (2011), Radiative forcing due to changes in ozone and methane caused by the transport sector, Atmos. Environ., 45, 387-394.

Olsen, S. C., D. J. Wuebbles, and B. Owen (2013a.), Comparison of global 3-D aviation emissions datasets, Atmos. Chem. Phys., 13, 429-441, doi:10.5194/acp-13-429-2013.

Olsen, S. C., G. P. Brasseur, D. J. Wuebbles, S. Barrett, H. Dang, S. D., Eastham, M. Z. Jacobson, A. Khodayari, H. Selkirk, A. Sokolov, and N. Unger, (2013b) Comparison of model estimates of the effects of aviation emissions on atmospheric ozone and methane, Geophys. Res. Lett., 40, 6004-6009, doi:10.1002/2013GL057660, 2013b.

Ott, L. E., K. E. Pickering, G. L. Stenchikov, D. J. Allen, A. J. DeCaria, B. Ridley, R.-F. Lin, S. Lang, and W.-K. Tao (2010), Production of lightning NOx and its vertical distribution calculated from three-dimensional cloud-scale chemical transport model simulations, J. Geophys. Res., 115, D04301, doi:10.1029/2009JD011880. 
Price, C. G. (2013), Lightning applications in weather and climate research, Surv. Geophys., 34, 755-767, doi:10.1007/s10712-012-9218-7.

Reinecker, M. M., M. J. Suarez, R. Todling, J. Bacmeister, L. Takacs, H.-C. Liu, W. Gu, M. Sienkiewicz, R. D. Koster, R. Gelaro, I. Stajner, and E. Nielsen (2008), The GEOS-5 Data Assimilation System-Documentation of versions 5.0.1, 5.1.0, and 5.2.0.NASA/TM-2008104606, Vol. 27, Technical Report Series on Global Modeling and Data Assimilation, 118 pp., available at: http://gmao.gsfc.nasa.gov/systems/geos5/ [Accessed 11 Jul 2011].

Schumann, U., and H. Huntrieser (2007), The global lightning-induced nitrogen oxides source, Atmos. Chem and Phys., 7, 3823-3907.

Sillman, S. (1999), The relation between ozone, NOx, and hydrocarbons in urban and polluted rural environments, Millennial Review series, Atmos. Environ., 33, 12, 1821-1845.

Tilmes, S., J.-F. Lamarque, L. K. Emmons, A. Conley, M. G. Schultz, M. Saunois, V. Thouret, A. M. Thompson, S. J. Oltmans, B. Johnson, and D. Tarasick (2012), Technical Note: Ozonesonde climatology between 1995 and 2011: description, evaluation and applications, Atmos. Chem. Phys., 12, 7475- 7497, doi:10.5194/acp-12-7475-2012, 2012.

Tilmes, S. J.-F. Lamarque, L. K. Emmons, D. E. Kinnison, P.-L. Ma, X. Liu, S. Ghan, C. Bardeen, S. Arnold, M. Deeter, F. Vitt, T. Ryerson, J. W. Elkins, F. Moore, J. R. Spackman, and M. Val Martin (2015), Description and evaluation of tropospheric chemistry and aerosols in the Community Earth System Model (CESM1.2), Geosci. Model Dev., 8, 1395-1426, doi:10.5194/gmd-8-1395-2015, 2015.

van Vuuren, D. P., et al. (2011), The representative concentration pathways: an overview, Climatic Change, 109, 5-31.

Weber, M., S. Dikty, J. P. Burrows, H. Garny, M. Dameris, A. Kubin, J. Abalichin, and U. Langematz, (2011), The Brewer-Dobson circulation and total ozone from seasonal to decadal time scales, Atmos. Chem. Phys., 11, 11221-11235, doi:10.5194/acp-11- 11221-2011, 2011.

Wild, O. (2007), Modeling the global tropospheric ozone budget: exploring the variability in current models, Atmos. Chem. Phys., 7, 2643-2660.

Wilkerson, J. T., M. Z. Jacobson, A. Malwitz, S. Balasubramanian, R. Wayson, G. Fleming, A. D. Naiman, and S. K. Lele (2010), Analysis of emission data from global commercial aviation: 2004 and 2006, Atmos. Chem. Phys., 10, 6391-6408, doi:10.5194/acp-10-6391-2010.

WMO (World Meteorological Organization), Scientific Assessment of Ozone Depletion: 1998, Global Research and Monitoring Project—Report No. 44, Geneva, Switzerland, 1999.

Wong, J., M. C. Barth, and D. Noone (2013), Evaluating a lightning parameterization based on cloud-top height for mesoscale numerical model simulations, Geosci. Model Dev., 6, 429-443, doi:10.5194/gmd-6-429-2013. 
We calculated the impact of NOx emissions from lightning on the production of aviation-induced ozone.

Three sensitivity studies were conducted with varying levels of NOx emissions (LNOx) from lightning.

By doubling LNOx the global mean aviation-induced $\mathrm{O}_{3}$ burden decreased by about $18 \%$. 
Technical Report Documentation Page

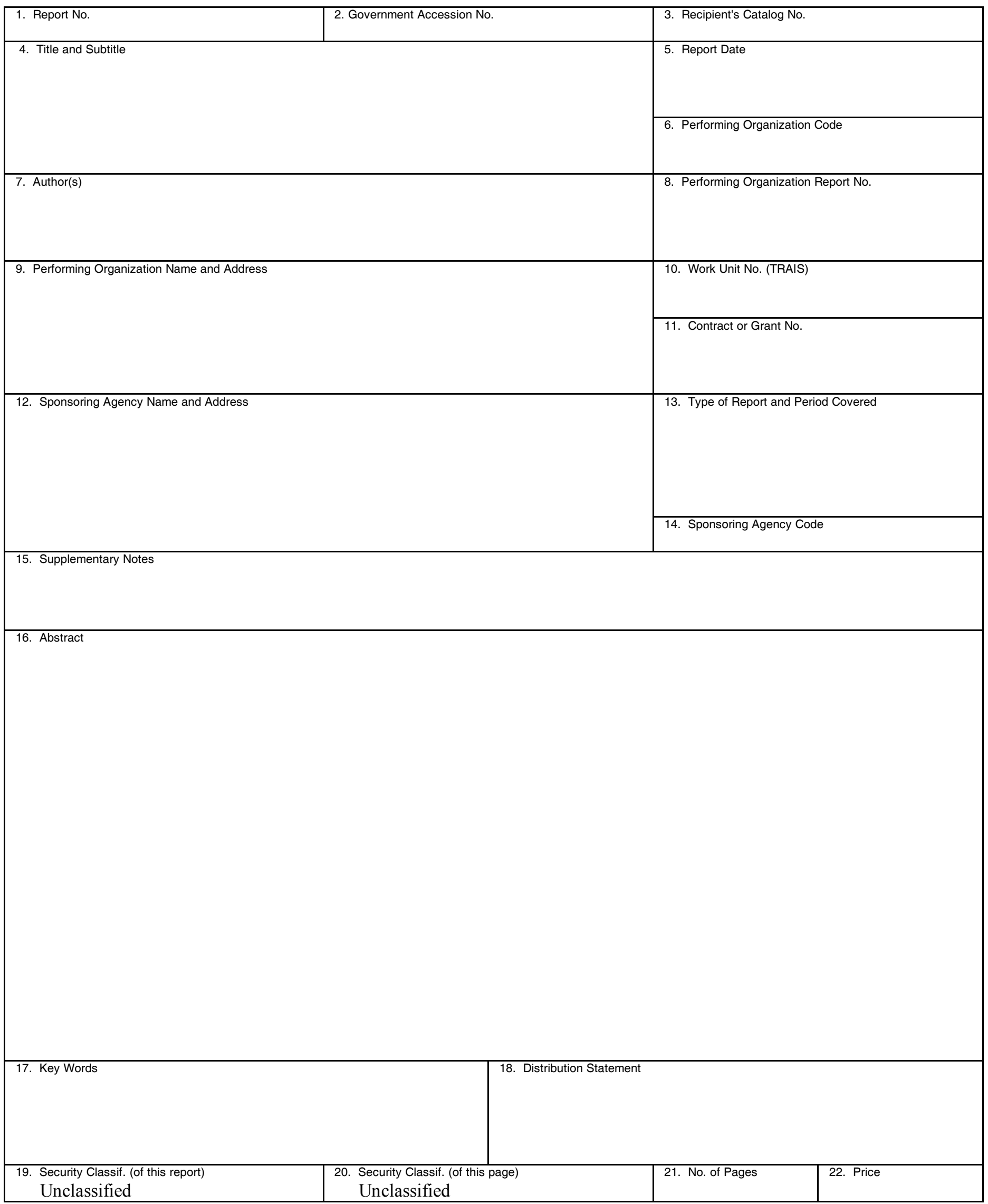

Form DOT F 1700.7 (8-72) Reproduction of completed page authorized

